\title{
At-Turats
}

Jurnal Pemikiran Pendidikan Islam

journal homepage: http://jurnaliainpontianak.or.id/index.php/atturats

\section{PENERAPAN ANALISIS MULTIDIMENSIONAL SCALING UNTUK MEMETAKAN PERSEPSI STAKEHOLDERS TERHADAP MUTU LULUSAN IAIN PONTIANAK}

\author{
Sumin \\ Fakultas Syari'ah Dan Ekonomi Islam (FSEI) \\ Institut Agama Islam Negeri (IAIN) Pontianak \\ e-mail : amien.ptk@gmail.com
}

\begin{abstract}
A B S T R A K
All society of academicians IAIN Pontianak must supporting vision and mission of IAIN Pontianak for the sake of quality of graduates who have higher competency and international insight one of concrete effort is doing community satisfaction survey towards the quality of graduates of IAIN Pontianak as external information source, next data perceptive analyzed with appropriate statistic tool, one of application tool is Multidimentional Scaling Tests (MDS). This research using descriptive methods (descriptive research) with the intention of making emphirical description Multidimentional Scaling Application (MDS) on stakeholders perceptive to map the quality of garduates of IAIN Pontianak. Population on this research is IAIN stakeholders in Pontianak, that is community which directly connected to graduates of IAIN Pontianak, or private institution or government as graduates of IAIN Pontianak user. Sample of this research using purposive methods sampling 100 respondents. IAIN segmentative of quality variables that has negative perceptive by community is Disciplines ( X9) and Motivates (X11), IAIN segmentative variables that have positive perceptive by stakeholders are Integrity / Ethics variables and Morality ( X1), Professionalism at works (X2), Insight between disciplines (X3), Leadership( X4), Teamworks( X5), Foreign Language Ability (X6), Communication Ability (X7), Using Information Technology (X8), Honesty (X10), Work Ethics(X12), Innovative and Creativity (X13), Solving Problems Ability (X14). There is high competition between 3 higher education in Pontianak. Those are: IAIN, Poltekes and Polnep. As spatial IAIN Pontianak closer to UNTAN, it is also means that UNTAN is the strongest competitor of IAIN Pontianak.
\end{abstract}

Key words: MDS, Perceptive Map, Graduates quality, IAIN Pontianak

\section{PENDAHULUAN}

Tuntutan masyarakat terhadap mutu produk dan layanan pendidikan tinggi semakin hari akan semakin tinggi. Apalagi dengan adanya kompetisi tenaga kerja antar bangsa sebagai dampak globalisasi. Oleh sebab itu, pemerintah berusaha mebudayakan mutu penyelenggaraan pendidikan tinggi dengan berbagai instru-men diantaranya akreditasi dan penjaminan mutu internal perguruan tinggi.
Diharapkan pembudayaan mutu ini pada akhirnya berhasil meningkatkan produk dan layanan pendidikan tinggi sehingga baik lulusan maupun produkproduk lainnya mempunyai nilai kompetitif secara global. Tuntutan paradigmaa baru yang berkaitan dengan prinsip mutu tersebut diatas semakin dipertegas dengan terbit-nya peraturan pemerintah (PP) Republik Indonesia(RI) Nomor 19 tahun 2005 tentang Standar Nasional Pendidikan (SNP). Pasal 51 ayat 2 dari PP RI tersebut menyatakan bahwa 
semua satuan pendi-dikan pada jalur formal dan non formal wajib melaksanakan mutu pendidikan.

Institut Agama Islam Negeri (IAIN) ontianak menyambut tuntutan paradigma baru prinsip mutu dalam penyelenggaraan pendidikan tinggi tersebut secara positif, sebab pada dasarnya upaya peningkatan mutu pendidikan bukan hanya merupa-kan pemenuhan terhadap tuntutan pera-turan tetapi lebih merupakan pemenuhan terhadap tuntutan Stake-holders yang semakin kritis. Berkaitan dengan hal ini IAIN Pontianak telah melakukan berbagai upaya termasuk di-antaranya adalah upaya menerapkan sistem manajemen mutu sebagai sarana pelaksanaan kegiatan penjaminan mutu.

Upaya penerapan sistem manajemen mutu telah dirintis sejak tahun 2014, diawali dengan kegiatan sosialisasi sistem penjaminan mutu ke semua unsur organisasi IAIN Pontianak. Kemudian disusul dengan pelatihan auditor mutu akademik internal dengan tujuan untuk menyiapkan tenaga-tenaga yang memahami sistem penjaminan mutu dan prinsip- prinsip audit internal disemua fakultas di lingkungan IAIN Pontianak. Disamping itu, telah dilakukan penyusunan dokumen-dokumen yang digunakan seba-gai landasan substansi penjaminan mutu tingkat Institut, selanjutnya pada tahun 2014 dan tahun 2015 telah dilakukan kegiatan monitoring dan evaluasi serta audit mutu internal, kegiatan tersebut dilakukan sebagai upaya untuk menjamin terlaksananya standar mutu IAIN Pontianak pada semua level dan unit pelayanan di lingkungan IAIN Pontianak.

Berdasarkan permasalahan terse-but, untuk memastikan terlaksananya proses penjaminan mutu yang sesuai standar dan untuk melengkapi informasi dari hasil audit dan monitoring internal, perlu dilakukan kegiatan survei kepuasan masayarakat yang bersentuan langsung dengan alumni (lulusan) IAIN Pontianak, dengan maksud untuk mengklarifikasikan dan memetakan faktor-faktor apa yang masih kurang dan faktor apa yang telah terpenuhi atau dipertahankan serta faktor apa yang perlu diperbaiki atau ditingkatkan.

Penelitian ini dilaksanakan untuk mengetahui dan memetakan persepsi Stake-holders terhadap lulusan IAIN Pontianak dengan menggunakan analisis statistik multivariate pensekalaan dimensi ganda (multidimensional scaling). Multidimen-sional Scaling (MDS) merupakan salah satu alat analisis multivariat yang berhubungan dengan penempatan beberapa objek pada suatu peta multidimensional yang ditentukan oleh konsumen berda-sarkan proximities (nilai kedekatan) antara beberapa objek tersebut.

Multidimensional Scaling (MDS) adalah teknik statistika yang digunakan untuk memetakan atau mencari konfigurasi sejumlah obyek dalam ruang berdimensi rendah berdasarkan ukuran kesamaan (similiarity) maupun perbedaan (dissi-malirity) antar stimulity atau obyek yang diteliti. Obyek yang saling berdekatan dalam konfigurasi menunjukkan bahwa obyek -obyek tersebut relatif sama satu sama lain. Berdasarkan tipe data yang digunakan maka MDS dibagi menjadi dua yaitu: MDS metrik dan MDS non metrik. MDS metrik digunakan untuk data berskala rasio dan interval sedangkan MDS non metrik digunakan untuk data berskala nominal dan ordinal. Penskalan Dimensi Ganda Metrik mentransformasi jarak antar obyek dalam suatu matriks ke dalam jarak antar obyek pada peta konfigurasi.

Prinsip Dasar dan Tujuan Analisis Analisis Multidimensional Scalling (MDS) merupakan salah satu teknik multivariat yang dapat digunakan untuk menentukan posisi suatu obyek lainnya berdasarkan penilaian kemiripannya. MDS disebut juga Perceptual Map. MDS berhubungan dengan pembuatan peta persepsi untuk menggambarkan posisi sebuah obyek dengan obyek lainnya 
berdasarkan kemiripan obyek -obyek tersebut. MDS juga merupakan teknik yang bisa membantu peneliti untuk mengenali (mengidentifikasi) dimensi kunci yang mendasari evaluasi objek dari responden (pelanggan).

Seluruh sivitas akademika IAIN Pontianak dituntut untuk mendukung visi dan misi IAIN Pontianak demi terwujudnya mutu lulusan yang memiliki komptensi yang tinggi dan berwawasan internasional, salah satu upaya konkrit adalah dengan melakukan survei kepuasan masyarakat terhadap mutu lulusan IAIN Pontianak sebagai sumber informasi eksternal, selanjutnya data persepsi yang diperoleh dianalisis dengan alat statistik yang sesuai, salah satu alat yang diterapkan adalah uji Multidimensional Scaling (MDS). Berdasarkan permasalahan terse-but, maka masalah penelitian ini dapat dirumuskan sebagai berikut:

1. Bagaimana deskripsi persepsi Stakeholders terhadap mutu lulusan IAIN Pontianak berdasarkan Integritas (Etika dan Moral), Keahlian berda sarkan bidang ilmu (Profesionalisme), Keluasan wawasan antar disiplin ilmu, Kepemimpinan, Kerjasama da- lam tim, Kemampuan bahasa asing, Kemampuan berkomunikasi, Penggu-naan teknologi Informasi, Kedisip-linan, Kejujuran, Motivasi Kerja, Etos Kerja, Inovasi dan kreativitas dan Kemampuan menyelesaikan masalah ?

2. Bagaimana segmentasi pasar dari lulusan IAIN Pontianak dibandingkan dengan perguruan tinggi lain di Kota Pontianak ?

3. Bagaimana posisi pasar IAIN Pontianak dibandingkan dengan perguruan tinggi lain di Kota Pontianak?

Mengacu pada rumusan masalah di atas, maka ruang lingkup dalam penelitian ini dibatasi pada kasus pemetaan persepsi Stakeholders terhadap mutu lulusan IAIN Pontianak menggunakan analisis Multidimensional Scaling Non Metrik berdasarkan variabel Integritas (Etika dan Moral), Keahlian berdasarkan bidang ilmu (Profesionalisme), Keluasan wawasan antar disiplin ilmu, Kepemimpinan, Kerjasama dalam tim, Kemampuan bahasa asing, Kemampuan berko-munikasi, Penggunaan teknologi Infor-masi, Kedisiplinan, Kejujuran, Motivasi Kerja, Etos Kerja, Inovasi dan kreativitas dan Kemampuan menyelesaikan masalah. Variabel penelitian diadobsi dari Peraturan Presiden Nomor 8 Tahun 2012 tentang Kerangka Kualifikasi Nasional Indonesia dan Peraturan Menteri Pendidikan Riset dan Teknologi Pendidikan Tinggi Nomor 44 Tahun 2015 tentang Standar Nasional Pendidikan Tinggi.

Sejalan dengan rumusan masalah, maka yang menjadi tujuan dilakukannya penelitian ini adalah sebagai berikut:

1. Untuk mengetahui persepsi Stakeholders terhadap mutu lulusan IAIN Pontianak berdasarkan Integritas (Etika dan Moral), Keahlian berdasarkan bidang ilmu (Profesionalisme), Kelua-san wawasan antar disiplin ilmu, Kepemimpinan, Kerjasama dalam tim, Kemampuan bahasa asing, Kemam-puan berkomunikasi, Penggunaan teknologi Informasi, Kedisiplinan, Kejujuran, Motivasi Kerja, Etos Kerja, Inovasi dan kreativitas dan Kemam-puan menyelesaikan masalah.

2. Untuk mengetahui segmentasi pasar dari lulusan IAIN Pontianak dibandingkan dengan perguruan tinggi lain di Kota Pontianak.

3. Untuk mengetahui posisi pasar IAIN Pontianak dibandingkan dengan perguruan tinggi IAIN di Kota Pontianak. 


\section{METODE PENELITIAN}

Penelitian ini menggunakan metode deskriptif (descriptif research) dengan maksud untuk membuat deskripsi empiris penggunaan analisis Multidimen-sional Scaling (MDS) pada pemetaan persepsi Stakeholders terhadap mutu lulusan IAIN Pontianak, pendekatan pene-litian yang digunakan adalah pendeka-tan kuantitatif dengan jenis penelitian survei.

Populasi pada penelitian adalah Stakeholders IAIN di Kota Pontianak, yaitu masyarakat yang berhubungan langsung dengan lulusan IAIN Pontianak, atau institusi swasta maupun pemerintah yang sebagai pengguna lulusan IAIN Pontianak.

Menurut Sugiyono (2005:118), sampel adalah bagian dari karakteristik yang dimiliki oleh populasi. Sampel juga dapat diartikan sebagai bagian dari populasi yang mempunyai sifat cukup dan representatif untuk mewakili populasi. Sampel dalam penelitian ini digunakan metode purposive sampling sebanyak 100 responden.

Penelitian ini dilakukan pada bulan Juni 2016 sampai dengan bulan November

2016. Peneliti akan melakukan pengumpulan data ulang jika data yang diperoleh dianggap belum menjawab tujuan penelitian.

Kemudian penelitian ini dilaksanakan di Kota Pontianak, survei akan dilakukan pada sekolah-sekolah untuk menjaring persepsi siswa terhadap kualitas lulusan mahasiswa Fakultas Tarbiyah dan Ilmu Keguruan dalam mengajar mata pelajaran Agama Islam, survei juga dilakukan di lembaga keuangan Bank atau Non Bank serta dunia usaha dan industri dengan maksud untuk menjaring persepsi konsumen terhadap mutu lulusan Fakultas Syari'ah dan Ekonomi Islam, survei juga dilakukan pada Kantor Urusan Agama dan Kementerian Agama Provinsi Kalimantan Barat dengan maksud untuk menjaring persepsi para pegawai terhadap lulusan Fakultas Dakwah Ushuludin Adab dan Dakwah.

Menurut Sugiyono (2005:31), variabel secara teoritis dapat didefinisikan sebagai atribut seseorang atau objek, yang mempunyai variasi antara satu orang dengan yang lain atau satu obyek dengan obyek yang lain. Pendapat senada diberikan oleh Hadi (2000:65), bahwa variabel adalah sebagai gejala yang bervariasi.

Variabel yang diteliti adalah mutu lulusan IAIN Pontianak yang terdiri dari faktor-faktor sebagai berikut:

1) Integritas (Etika dan Moral)

2) Keahlian berdasarkan bidang ilmu (Profesionalisme)

3) Keluasan wawasan antar disiplin ilmu

4) Kepemimpinan

5) Kerjasama dalam tim

6) Kemampuan bahasa asing

7) Kemampuan berkomunikasi

8) Penggunaan teknologi Informasi

9) Kedisiplinan

10) Kejujuran

11) Motivasi Kerja

12) Etos Kerja

13) Inovasi dan kreativitas

14) Kemampuan menyelesaikan masalah

Metode yang digunakan untuk mengumpulkan data dalam penelitian ini adalah komunikasi tidak langsung, komunikasi tidak langsung dilakukan dengan cara menyebarkan kuesioner kepada responden. Adapun Instrumen penelitian yang digunakan untuk mengumpulkan data adalah kuesioner. Kueisoner adalah sejumlah pertanyaan atau pernyataan tertulis yang digunakan untuk mempe-roleh informasi dari responden tentang hal-hal yang dia ketahui, yang digunakan utuk memperoleh data yang valid dan reliabel, serta dapat 
memberikan penjelasan bila pertanyaan tidak dimengerti oleh responden. Kueioner penelitian didesain seusai vairabel dan teori yang relevan dengan penelitian. Kuesioner disusun dengan Bahasa yang sederhana sehingga semua responden dapat dengan mudah memahami maksud dari setiap pertanyaan atau pernyataan yang diajukan berisi tentang variabel mutu lulusan IAIN Pontianak.

Kuesioner diisi oleh responden sesuai pertanyaan/pernyataan dengan pilihan jawaban multiple choice (pilihan ganda).

Data merupakan kumpulan angka, fakta, fenomena atau keadaan yang merupakan hasil pengamatan, pengukuran, atau pencacahan terhadap karakteristik atau sifat dari obyek yang dapat berfungsi untuk membedakan obyek yang satu dengan lainnya pada sifat yang sama (Solimun, 2001:2). Jenis data dalam penelitian ini adalah adalah data kulaitatif yang dikuantitatifkan dengan menggunakan skoring. Sumber data yang digunakan adalah data primer yang diperoleh dari hasil survei dengan penyebaran instrument berupa angket (kuesioner) kepada Stakeholders IAIN Pontianak yang telah dipilih sebagai sampel dalam penelitian ini.

Penelitian ini menggunakan derajat pengukuran ordinal, skala ordinal adalah skala pengukuran yang menghasilkan data ordinal, yaitu: data yang mengandung unsur penamaan dan memiliki unsur urutan $($ order $=$ urut). Ciri dari data ini kategori data disusun berdasarkan urutan logis dan sesuai dengan besarnya karakteristik yang dimiliki. Penggunakan skala ordinal dimaksudkan untuk mengetahui persepsi responden terhadap kesesuaian mutu lulusan IAIN Pontianak.

Kesesuaian mutu tersebut disusun dalam kategori yang bergradasi dari sangat setuju (ST), setuju (S), kurang setuju (KS), tidak setuju (TS) dan sangat tidak setuju (STS) sesuai aturan pensekalaan yang direkomendasikan oleh Likert.

Analisis data yang digunakan untuk menjawab tujuan penelitian yang pertama adalah menggunakan metode deskriptif, selanjutnya untuk menjawab tujuan penelitian yang kedua dan ketiga dilakukan dengan cara memetakan persepsi Stakeholders menggunakan analisis Multidimensional Scaling (MDS) sehingga diperoleh sementasi pasar dan posisi pasar IAIN Pontianak.

\section{HASIL DAN PEMBAHASAN}

Berdasarkan hasil analisis data yang diperoleh dari penyebaran angket secara purposive sampling kepada 100 orang Stakeholders IAIN Pontianak, selama bekerjasama atau berhubungan secara langsung dengan lulusan (alumni) IAIN Pontianak selama ini, sebagian besar responden mempersepsikan bahwa secara umum lulusan IAIN Pontianak sudah bermutu baik dan tidak kalah saing dengan lulusan peguruan tinggi dalam bidang sosial keagamaan, bahkan dengan lulusan peguruan tinggi umum. Hal ini menunjukan bahwa IAIN Pontianak sebagai lembaga penyedia memiliki core bisnis menyediakan lulusan perguruan tinggi yang bermutu dan siap bersaing dalam dunia kerja, sudah cukup mampu menunjukkan eksistensinya dan membuktikan visi IAIN Pontianak "Ulung dan terbuka dalam kajian dan riset keilmuan, keislaman, serta kebudayaan Borneo", dengan visi Menyelenggarakan pendidikan tinggi yang ulung dalam kajian keilmuan, keislaman dan kebudayaan Borneo; dan membentuk akademisi yang berakhlak mulia, mandiri, dan bermanfaat bagi bangsa dan kemanusiaan.

Segmentasi pasar IAIN Pontianak sudah sanggup mempersiapkan mutu lususan yang memiliki Integritas/Etika dan Moral, Profesionalisme dalam bekerja, Keluasan Wawasan antar disiplin ilmu, Kepemimpinan, Kerjasama dalam tim, 
Kemampuan Bahasa Asing, Kemampuan Berkomunikasi, Penggunaan Teknologi Informasi, Kejujuran, Etos Kerja, Inovasi dan Kreativitas dan Kemampuan menyelesaikan masalah. Hal ini merupakan wujud perhatian dan penilaian public terhadap kualitas perguruan tinggi asal para alumni yang sudah dinilai postif dan mampu "menetaskan" lulusan bermutu.

Disamping penilaian positif terhadap 14 dimensi mutu lulusan, Stakeholders juga secara jujur menyatakan bahwa motivasi dan disiplin kerja lulusan IAIN Pontianak masih buruk atau dipersepsikan negatif, hal ini dapat dijadikan dasar bagi segenap sivitas akademika IAIN Pontianak, khususnya pengeola Program Studi dan Fakultas, hendaknya berusaha membuat program kerja tahunan yang mendukung upaya pembentukan budaya disiplin dan motivasi bagi siswa melalui berbagai kegiatan yang didukung, diprakarsai dan didanai oleh lembaga, sebagai wujud komitmen dan kepatuhan terhadap amanah dalam Peraturan Menteri Riset Teknologi dan Pendidikan Tinggi (Permenristekdikti) No. 44 Tahun 2015 tentang Standar Nasional Pendidikan Tinggi Pasal 39 butir (3) huruf c yang menyatakan bahwa "Perguruan tinggi dalam melaksanakan standar pengelolaan menjaga dan meningkatkan mutu pengelolaan program studi dalam melaksanakan program pembelajaran secara berkelanjutan dengan sasaran yang sesuai dengan visi dan misi perguruan tinggi".

Hasil penelitian ini juga mendapatkan sebuah informasi penting terkait posisi pasar atau posisi tawar IAIN Pontianak dibandingkan dengan perguruan tinggi sejenis (bidang sosial keagamaan) maupun perguruan tinggi umum baik negeri maupun swasta di Kota Pontianak. Stakeholders mempersepsikan IAIN Pontianak sebagai perguruan tinggi yang bersaing ketat dengan Universitas Tanjungpura (UNTAN) jika dilihat dari 14 dimensi mutu yang digunakan sebagai variabel dalam penelitian ini.
Fakta yang menarik dari hasil penelitian ini adalah ternyata IAIN tidak bersaing ketat dengan lulusan Universitas Muhammadyah (UMP) dan STIS yang merupakan perguruan tinggi dengan bidang kajian sejenis dengan IAIN Pontianak yaitu pada bidang sosial keagamaan. Hal ini karena IAIN Pontianak merupakan perguruan tinggi negeri yang menawarkan biaya yang relatif terjangkau dengan kualitas yang cukup baik, disisi lain ada beberapa program studi unggulan yang menjadi saingan Universitas Tanjungpura, yaitu; Pendidikan Guru Agama Islam, Pendidikan Guru Raudhatul Athfal, Pendidikan Guru Ibtada'iyah, Ekonomi Islam, Perbankan Syari'ah, Hukum Islam (Muamalah), Hukum Keluarga (Ahwalu Asyaksiyah) dan Juruan Komunikasi Penyiaran Islam dan Bimbingan Konseling Islam. Program studi tersebut memiliki banyak kemiripan dengan jurusan-jurusan yang ada di Fakultas Keguruan dan Ilmu Pendidikan Universitas Tanjungpura, Fakultas Hukum dan juga Fakultas Ekonomi.

Jurusan/Program Studi unggulan di IAIN Pontianak, ternyata sanggup menawarkan mutu yang relatif baik dan kompetitif dibandingkan dengan Universitas Tanjungpura Pontianak. Selain itu juga, program studi di lingkungan IAIN Pontianak yang mirip dengan program studi di Universitas Tanjungpura sekaligus dapat menjadi alternatif bagi para lulusan SMA/SMK jika tidak lulus tes penerimaan mahasiswa baru di Universitas Tanjungpura, atau yang memilih IAIN Pontianak atas kesadaran dan kemauan sendiri. 


\section{KESIMPULAN}

Berdasarkan hasil analisis dan pembahasan pada BAB IV, hasil penelitian ini dapat disimpulkan sebagai berikut.

1. Integristas/etika dan moral, kepemimpinan, dan kerjasama dalam tim dipersepsikan sangat baik oleh sebagian besar Stakeholders. Sedangkan profesionalisme dalam bekerja, keluasan wawasan antar disiplin ilmu, kemampuan bahasa asing, kemampuan berkomunikasi, penggunaan teknologi informasi, kedisiplinan, kejujuran, motivasi kerja, etos kerja, inovasi dan kreativitas, dan kemampuan menyelesaikan masalah dipersepsikan baik oleh sebagian besar responden. Dengan demikian maka dapat disimpulkan bahwa secara kumulatif 14 variabel mutu lulusan IAIN Pontianak dinilai baik oleh sebagian besar Stakeholders.

2. Segmentasi IAIN dari variabel yang dipersepsi negatif/jelek oleh masyarakat, karena ketiga titik variabel ini mempunyai jarak yang jauh terhadap titik-titik karakteristik. Varia-bel tersebut adalah Disiplin (X9) dan Motivasi (X11).

3. Segmentasi IAIN dari variabel yang dipersepsi positif/baik oleh masyarakat, karena variabel-variabel ini mempunyai jarak yang dekat terhadap titik-titik karakteristik. variabel tersebut adalah Integritas/Etika dan Moral (X1), Profesionalisme dalam bekerja (X2), Keluasan Wawasan antar disiplin ilmu (X3), Kepemimpinan (X4), Kerjasama dalam tim (X5), Kemampuan Bahasa Asing (X6), Kemampuan Berkomunikasi (X7), Penggunaan Teknologi Informasi (X8), Kejujuran (X10), Etos Kerja (X12), Inovasi dan Kreativitas (X13), Kemampuan menyelesaikan masalah (X14)

4. Perguruan tinggi yang berada pada kuadran I (kanan atas) adalah IAIN, Poltekes dan Polnep, hal ini menunjukkan bahwa terdapat persaingan yang ketat di atara 3 perguruan tinggi negeri tersebut, namun posisi IAIN berada cukup jauh dan lebih unggul dari pesaingnya, disisi lain secara spasial cukup dekat dengan Untan yang berada dikuadran III, hal ini juga bermakna bahwa Untan juga termasuk pesaing terkuat IAIN Pontianak.

5. Perguruan tinggi yang dipersepsi negatif/jelek oleh masyarakat, karena ketiga titik perguruan tinggi tersebut mempunyai jarak yang jauh terhadap titik-titik karakteristik dan berada pada kuadran yang negatif. Perguruan tinggi tersebut adalah STIE, ABA, UPB, dan IKIP-PGRI.

6. Perguruan tinggi yang dipersepsi positif/ baik oleh masyarakat, karena ketiga titik perguruan tinggi ini mempunyai jarak yang dekat terhadap titik-titik karakteristik dan berada pada kuadran yang positif. Perguruan tinggi tersebut adalah Akbid Aisiyah, Untan, IAIN, Polnep, Poltekes, UPB, UMP, Stikes, Akbid Aisiyah, Yarsi dan STIS.

\section{DAFTAR REFERENSI}

Abdi, H. 2006, Metric Multidimensional Scaling (MDS) : Analyzing Distance Matrices, The University of Texas at Dallas.

Borg,I., dan Groenen, P. 1997, Modern Multidimensional Scaling. Springer. 1st edition. New York
Boyd, Harper W., dkk. 2001. Manajemen Pemasaran. Edisi Kedua, Erlangga. Jakarta.

Chin W.W. \& Newsted P.R., (1999), "Structural Equation Modeling Analysis with Small Samples using Partial Least Squares", in: Hoyle R. (ed.) Statistical Strategies for Small 
Sample Research,

Publications, pp. 307-341.

Sage

Cox,T.F., dan Cox, M.A.A. 2001. Multidimensional Scalling, Chapman\&Hall, London.

Gabriel, K.R.(1971), The biplot graphic display of matrices with application to principal componentan alysis, Biometrika 58:453-467.

Ghozali, Imam. 2006, Structural Equation Modeling Metode Alternatif dengan

Partial Least Square, Badan Penerbit Universitas Diponegoro, Semarang.

Hair, Jr., J. F., Black, W. C., Babin, B. J., Anderson, R. E., \& Tatham, R. L. (2006).

Multivariate Data Analysis (6th ed.). Upper Saddle River, NJ: Pearson Prentice Hall.

Johnson, R.A, dan Wichern, D.W. 2002, Applied Multivariate

StatisticalAnalysis, PrenticeHall, EnglewoodClifts, NewJersey.

Kasali, Rehenal. 2007. Membidik Pasar Indonesia, Segmentasi, Targeting, Positioning, PT Gramedia Pustaka Utama, Jakarta.

Kotler, Philip dan Gray Amstrong. 2008. Prinsip-Prinsip Pemasaran. Edisi 1, Buku Jakarta: Erlangga.

Lamb. Charles. W. et.al, 2001. Pemasaran. Buku I, Edisi Pertama. Jakarta: Salemba Empat.

Peraturan Menteri Pendidikan dan Kebudayaan Nomor 49 Tahun 2014, Tentang Standar Nasional Pendidikan Tinggi, Jakarta.

Peraturan Menteri Pendidikan dan Kebudayaan Nomor 50 Tahun 2014, Tentang Standar Standar
Penjaminan Mutu Pendidikan Tinggi, Jakarta.

Peraturan Presiden Republik Indonesia Nomor 8 Tahun 2012, Tentang Kerangka Kualifikasi Nasional Indonesia, Jakarta.

Robbins, Stephen P., 2006. Perilaku Organisasi. Edisi Kesepuluh. Jakarta: Gramedia.

Simamora, B, 2001, Panduan Riset Perilaku Konsumen. Jakarta:PT Gramedia Pustaka Utama. UndangUndang Republik Indonesia Nomor 12 Tahun 2012 Tentang Pendidikan Tinggi, Jakarta.

Umar, Husein. 2003. Riset Pemasaran dan Perilaku Konsumen. Jakarta. Gramedia.

Wickelmaier, Florian. 2003. An Introduction to MDS. Sound Quality Research Unit, Aalborg Uiverity, Denmarg. 